\title{
AUSÊNCIA E CRISE NA POESIA BRASILEIRA CONTEMPORÂNEA: A POÉTICA DA "FALTA" EM FABRÍCIO CORSALETTI
}

Carolina Molinar Bellocchio

RESUMO

O presente texto visa analisar a condição da lírica no presente procedendo à análise da obra do poeta Fabrício Corsaletti. Valendo-se das proposiçóes de Marcos Siscar e de Gilles Lipovetsky, considera-se que Estudos para seu corpo (2007) apresenta poemas cuja sensaçáo de esgotamento do eu lírico acaba por explicitar a poética da "falta" que baliza estética e filosoficamente a sua poesia, situada em um tempo histórico cuja condição da crise e do esfacelamento das subjetividades perpassa a constituição lírica.

PALAVRAS-CHAVE: Poesia. Falta. Fabrício Corsaletti.

A poesia, no sentido que lhe dá a melhor modernidade poética, não é uma ponte para outra coisa, por exemplo o futuro. (...) Mostra-se como o lugar da crise. (...) Não é por antever ou apontar aquilo que falta, mas por transformar-se no interregno dessa falta. Talvez a poesia seja aquilo que falta. (SISCAR, 2010, p.116.)

ste trabalho objetiva investigar a subjetividade lírica na contemporaneidade, de modo mais específico a constituição do sujeito poético nos escritos do paulista Fabrício Corsaletti. Partindo da compreensão de que a poesia lírica há mais de um século se vale discursivamente dos espectros da fragmentação, das ruínas, da transitoriedade e de um certo 
mal-estar associado ao seu declínio e à crise que o embate com o tempo presente impóe, busca-se averiguar se o poeta contemporâneo e sua poesia compartilham ou colocam-se em posição de reavaliação/ruptura frente a tais instâncias. A condição de obra recém-publicada - Estudos para seu corpo (2007) foi lançada aproximadamente há seis anos - obriga o crítico - que se depara com a ausência de referências, versôes e pronunciamentos de afetos/ desafetos teóricos do poeta - a valer-se basicamente dos próprios poemas, isto é, da própria voz do sujeito lírico.

Esse proceder, aliás, menos que uma dificuldade de se lidar com a contemporaneidade através de um discurso "por-fazer" ao invés de um discurso “já feito", permite um olhar menos guiado pelas leituras críticas que se efetuam ao longo da história, tornando a enunciação da subjetividade poética em questão passível de análise sem filiaçóes a propostas teóricas a priori. $\mathrm{O}$ embate da crítica literária com o presente, portanto, possibilita partir dos dados - literários, culturais, econômicos, históricos, sociais - de que se dispóe, com o objetivo de construir interpretaçóes sobre o nosso tempo. Em consonância com Marcos Siscar (2010), pode-se dizer, afinal, "que vivemos uma época de privilégio da própria reflexão sobre o tempo presente." (SISCAR, 2010, p. 185), e que este deve ser retomado verdadeiramente como uma questão - ao contrário dos exercícios correntemente feitos pela crítica, como demonstra o autor:

Não seria incorreto dizer (...) que o discurso teórico raramente considerou o presente, ele próprio, como um tema ou como uma estrutura, ou pelo menos uma questão relevante em si mesma, com a exceção notória (...) do discurso filosófico. De maneira geral, a partir de um viés histórico (...) o analista constata, isto é, reconhece dominâncias, recorrências, pontos de ruptura que caracterizam para ele sua contemporaneidade; descreve o presente para poder compreendê-lo e eventualmente julgá-lo. Situa-o como um objeto ou um estado de coisas que se observa do exterior, como um conjunto de dados mais ou menos ordenável, que se pode, portanto, delimitar em sua particularidade." (SISCAR, 2010, p. 186) 
O que se coloca em foco nessa argumentação é o fato de parcela da crítica literária reconhecer o presente como algo colado à própria realidade, donde se inferem leis de funcionamento, axiomas pré-determinados e fundamentaçóes concebidas de antemão, levando-se em consideração apenas o caráter de atualidade ${ }^{1}$, isto é, de informaçóes que se propóem neutras a respeito da constituição desse tempo. Ora, a noção de atualidade se distancia tremendamente da noção de presente, uma vez que esta se constitui como instância essencialmente projetada e construída:

O presente se constitui, antes de mais nada, como efeito de atualidade, como algo que tornamos atual para a consciência através de um ato de atenção; existe nele uma intencionalidade que é preciso considerar. (...) Em outras palavras, não há presente sem interpretação. (SISCAR, 2010, p. 188)

Sendo interpretação, portanto, seu caráter é derivado e por isso ela se poderia entender sob a forma da figura. Para compreender esta ideia, não se pode perder de vista que sua constituição é distinta de uma ideia de totalidade, uma vez que a compreensão da atualidade é permeada pela operação de montagem, processo esse que recorta, edita, seleciona, exclui o diferente, sendo assim também a noção de atualidade: compreendida como algo supressivo e excludente. Dessa constituição derivada, entende-se que o presente nunca é igual a ele mesmo, o que o constitui, portanto, como desvio e figura.

E é o presente como desvio e figura o vetor que orienta este trabalho, pois nele se empreende uma construção discursiva, figural, interpretativa da obra de Fabrício Corsaletti, partindo essencialmente dos elementos simbólicos, linguísticos e metafóricos identificados e inventariados a partir da leitura crítica dos poemas e que são, finalmente, articulados a partir de uma determinada intencionalidade e concebidos como interpretação do analista.

1 O sentido de atualidade, em Siscar (2010, p.188), aproxima-se da noçáo de atualização que se tem na contemporaneidade. Ler os jornais, estar a par dos acontecimentos midiáticos, compreender a dinâmica das relaçóes e da estrutura social, por exemplo, seriam aspectos da ordem do conhecimento da atualidade. 
Partindo dessa compreensão de que não há o presente em si, sendo ele um vazio o qual as interpretaçóes preenchem, pode-se associar a sua imagem àquilo que "falta":

O presente seria assim um núcleo carente, esvaziado de sentido; faltar-lhe-ia sempre um pouco mais de presente, o necessário encontro consigo mesmo. O presente é o momento da falta, da ausência que o discurso vem a complementar ou ocupar voluntariosamente como manifestação de um desejo. (SISCAR, 2010, p.196)

E, coincidentemente, dentre os vários discursos que constatam esse drama de origem cujas interpretaçóes e figuraçóes vêm a oferecer respostas, a "literatura talvez seja aquele de que maneira mais efetiva consiga vislumbrar ou dar a ver o presente como diferença de si, como algo que mantém sempre retesado a força afirmativa do discurso"(SISCAR, 2010,p.188). Assim, se a literatura como discurso enxerga esta sua tarefa de desvio frente à falta que o presente constitui, a poesia de Corsaletti se junta a este coro. E como a poesia, enquanto literatura, reconhece essa falta, a poesia de Corsaletti se posiciona justamente no sentido de agravá-la, explicitando-a na sua escritura, isto porque "a falta" é algo que se pressente ali, pois o presente para ele é tempo difícil de ser pensado, compreendido e, principalmente, de ser construído. Assim também o é com o poema: curto, ausente e apático, ele sugere a materialização dessa falta.

A indisposição do poeta com o presente, entretanto, não é recente; esse traço discursivo que canta a sua "ilegitimidade" conta pelo menos 150 anos, sendo ela, na verdade, sintoma constitutivo da modernidade poética. Desde Baudelaire, passando por Tristan Corbière, Villiers de l'Isle-Adam, Rimbaud, Verlaine a Mallarmé, a crise prospera, sendo o

tema do mal-estar, do presente como época de desolação, da falta de condiçóes de poesia, da falta de poesia ou da poesia que falta, em suma, mais (ou menos) do que uma informaçáo ou uma constatação sociocultural: ela parece constituir o modo 
pelo qual a poesia apresenta modernamente seu 'programa', seu sentido dentro de conjunto de vozes sociais. (SISCAR, 2010, p. 42-43)

Associadas ficam, portanto, a ideia de falta que o presente constitui e também a noção de que a crise, ou o mal-estar, é exatamente a manifestação dessa falta do presente, isto é, a identidade entre crise, o presente e "a falta" são as condiçóes que a poesia lírica ao mesmo tempo ergue e enfrenta.

Se naquele momento de constituição o discurso da crise se realizava de modo sacrificial, isto é, o poeta se sacrificava ao oferecer-se discursivamente como vítima a ser imolada em sua poesia, o mal-estar diagnosticado na poesia contemporânea dispensa esse tom sacrificial, uma vez que o momento de heroísmo contraditório ou paradoxal, enfim, patético, perdeu-se em meio a um background mais de apatia do que de sentimentos ferozes como a hostilidade aos poetas malditos, por exemplo ${ }^{2}$. O marasmo, dessa maneira, é a sensação e a ação que resta frente à hostilidade do presente.

Apesar de reaçóes diversas, seja o ódio e a vitimização do poeta, seja a apatia e o marasmo, todos são frutos de uma constatação (SISCAR, 2010, p.10), a saber: "o desastre do presente", afinal, é o que alimenta a lírica. O que importa aqui é notar que apesar de certa heterogeneidade, algumas marcas são percebidas mais como continuidade do que como ruptura ${ }^{3}$. Assim, apesar de inúmeros indícios que apontem uma intensa variedade constitutiva

2 A respeito do mal-estar na contemporneidade brasileira, Siscar transcreve os versos de um poema de Carlito Azevedo que pontua a sensação incômoda que o presente poético oferece: "Ninguém é o / mesmo / depois de um / cataclisma / Menos que / espasmo, / Mais do que / marasmo, / Fica aquela / cisma. (Collapsus linguae, 1992).”. Duas liçóes do presente ficam para os leitores: o título da obra de Carlito, Collapsus linguae, aponta a impossibilidade e a fratura da poesia ao diagnosticar o colapso da linguagem bem como é marcado o aspecto de apatia que não só ronda, mas principalmente emana dos poetas de agora.

3 Tome-se de exemplo os contemporâneos de Hugo Friedrich. Eles compreendiam a heterogeneidade da produção poética do início do século XX como um momento absolutamente dissociado e sem ligaçóes entre si. Segundo ele, "a crítica da lírica contemporânea comete quase sempre o erro de considerar somente o país que está sendo focalizado e nos seus últimos vinte ou trinta anos. Assim, a poesia parece assumir características de uma extraordinária 'ruptura' e, entre a lírica de 1945 e a de 1955, nota-se, com espanto, uma distância que, na verdade, não corresponde nem mesmo ao intervalo existente entre dois segundos." (FRIEDRICH, 1978, p. 9). 
sinalizarem uma aparente impossibilidade de compreender toda a produção contemporânea a partir do caráter de continuidade em relação à lírica moderna, o crítico do momento presente deve tentar não deixar que se perca de vista a permanência de algumas instâncias comuns à produção poética do século XIX ao século XXI. Assim, faz-se necessário avaliar em quais pontos identifica-se uma continuidade e em quais outros ocorre uma ruptura, sendo esta discussão uma das questóes que perpassam este trabalho.

Seguindo essa perspectiva, observa-se que a subjetividade poética em Corsaletti fia-se na concepçáo da poesia como o lugar materializado da falta, isto é, instância orientada tanto pela crise, quanto empenhada pelo presente. Por esse motivo, seráo utilizados aqui operadores que agenciam o pouco e uma certa negatividade, com o intuito de demarcar o discurso poético de Corsaletti como manifestação da ausência e da falta constitutivas do presente. A interpretação se constrói através do seguinte ponto: o poeta parte da assunção de que o que se diz, de modo geral, é regido por condiçóes de apatia, vacuidade, indiferença. Os versos "muito delicadamente / não estou escrevendo / estou desrecontando" (CORSALETTI, 2007, p.25) ou o poema "Anulação", que diz "Não vai sair nada / além de três / ou quatro palavras / que não quero mais usar / eu poderia esperar / mas no fundo / qualquer / imagem me serve / em todas / me anulo (...)" escancaram a opção de se manter poeticamente "calado", certamente na medida em que isso é possível: por meio de recursos que denunciam a excessiva fala do indivíduo contemporâneo, conforme aponta Lipovetsky (2005, p.24): "quanto mais a gente se expressa, menos há o que dizer; quanto mais a subjetividade é solicitada, mais o efeito é anônimo e vazio.", Corsaletti, enquanto sujeito contemporâneo, mas essencialmente sujeito lírico, coloca em questão a validade do expressar-se no momento presente.

Assim, ele faz os leitores atentarem para a culminação do "processo de personalização" (LIPOVETSKY, 2005, p. VXI) e a necessidade de se expressar a todo custo, mesmo que seja para nada dizer. Em tempos em que a escrita avança em diários pessoais curiosamente disponibilizados na internet, em que a criação de identidades virtuais supera qualquer possibilidade tanto de vivência quanto de experiência, e a necessidade de se definir em um perfil "descolado", nas redes sociais, leva ao extremo a tarefa lírica de se exprimir, o questionamento da escrita "faltosa" de Corsaletti parece se estender ao poeta: precisaria ele também expressar-se utilizando o código literário, isto é, a litera- 
tura enquanto instituição para satisfazer a necessidade prosaica do indivíduo contemporâneo em traduzir-se através da escrita? O que distinguiria o texto de Corsaletti dos inúmeros registros literários que se constituem a partir de um possível biografismo e de uma "ausência" de procedimentos metalinguísticos e metafóricos?

O fato de o autor ser graduado em Letras o torna, de certo modo, um iniciado nas artes da palavra e também da crítica da palavra. No entanto, tal dado não lhe acrescenta "vocação" para poesia, pois por si só não situa sua escrita em uma instância literária. A publicação da sua obra através de uma Editora, por sua vez, daria força ao projeto de constituir-se discursivamente como poeta. Assim, por meio da "Companhia das Letras" lançou Estudos para seu corpo, obra que reúne quatro de seus livros: Movediço, O sobrevivente, História das demoliçóes e, finalmente, o quarto e que intitula a coleção, Estudos para seu corpo ${ }^{4}$.

Este foi reconhecido pela crítica como "uma aposta acertada na área de poesia da 'Companhia das Letras'” que, segundo Fabrício Carpinejar, se caracteriza pela constante ambivalência: de dicção ("parte do sussurro e alcança o grito"; "vai da poesia mais realista, (...) que trafega da concisão irônica aos versos longos dialogados"), de tom (se alterna entre "a crueldade da infância e a suavidade do amor pelas mulheres"), de releitura (que parte da perspectiva da "exaltação das ruínas, do apodrecimento e das sobras (...) a um otimismo tímido e um lirismo bem-humorado, flertando com a canção e os epigramas à maneira de Francisco Alvim") (CARPINEJAR, 2007).

Carlos Machado (2007) também compreende Estudos para o seu corpo a partir desse direcionamento duplo e enfatiza que esse movimento também é caracterizado pelo caráter "coloquial e completamente desmetaforizado" dessa poesia. Essas marcas do cotidiano, portanto, são bem significativas e configuram, segundo aquele, "o rumo (ou melhor: um dos rumos) da palavra poética nestes primeiros anos do século XXI".

4 Sua última publicação de poesia, Esquimó (2010), cuja crítica oscilou em classificar ora como digna de um "Poetinha” (Fábio Vitor, Folha de S. Paulo, 17/02/2010.) - em referência a Vinícius de Moraes - ora como irônicas alfinetadas ao estilo de um Chacrinha - marcada pela brincadeira de mau-gosto e, portanto, poeticamente medíocre, por Dolhnikoff - , foi premiada com a categoria de Melhor Livro na Sexta Edição do Prêmio Bravo! Bradesco Prime de Cultura em 2010 e concorreu, juntamente com outros 49 títulos, ao prêmio Portugal Telecom de Literatura Portuguesa em 2011. 
Atualmente colunista da Revista São Paulo, Corsaletti ali escreve crônicas e publica alguns poemas ocasionais. Talvez se localize aí uma certa familiaridade com os indícios de uma escrita leve e informal, que dá primazia a um diálogo muito aberto e próximo ao/com do/o leitor.

A coletânea apresenta a obra de Corsaletti cronologicamente, isto é, conforme havia sido produzida e publicada anteriormente. Assim, a leitura dos quatro livros revela não só um amadurecimento literário, com a instauração de novos temas, novas imagens, mas também revela uma trajetória que faz confundir o biográfico e o poético. Durante o caminhar da leitura, pode-se relacionar fatos da vida do escritor, a exemplo da sua infância e adolescência passadas no interior; sua seguinte mudança para a capital paulista; a dolorosa adaptação ao ambiente urbano conturbado, aos temas tratados pelo sujeito lírico daqueles poemas 5 .

Vale aqui uma ressalva quanto à hipótese de que se possa confundir essas duas instâncias, chegando apenas a considerar a obra de Corsaletti como eminentemente biográfica, e que, além disso, esta seja sua característica mais relevante e notória. Essa confusáo se torna especialmente fácil de se estabelecer uma vez que a lírica é um gênero em que o sujeito tem primazia. Torna-se, assim, muitas vezes difícil a separação entre o "eu" lírico e o "eu" biográfico. O poema "fabrício:" (CORSALETTI, 2007, p. 106), por exemplo, indica como o escritor reforça tal confusão entre os "eus", ao ter como título do poema seu próprio nome como vocativo e também ao tratar essa segunda pessoa (ti) com alguém que ele, ao mesmo tempo, dialoga e identifica como sendo ele mesmo.

Candido (2006, p. 35) afirma que o valor de uma obra literária pode ser mesurado pela eficiência em mesclar elementos náo literários, tais como "impressóes, paixóes, ideias, fatos, acontecimentos, que são a matéria-prima [...]" do escritor com a sua habilidade formal, sendo o efeito deste processo o próprio texto literário.

Em suma, importa no estudo da literatura o que o texto exprime. A pesquisa da vida e do momento vale menos para estabelecer uma verdade documentária, frequentemente inútil,

5 Fabrício Corsaletti é natural de Santo Anastácio, cidade do interior paulista cuja população em 2006 era estimada em torno de21.300 habitantes. Nascido em 1978, mudou-se para São Paulo com a finalidade de continuar seus estudos em nível superior, granduando-se em Letras pela USP. 
do que para ver se nas condições do meio e na biografia há elementos que esclareçam a realidade superior do texto [...] (CANDIDO, 2006, p. 37)

Dessa maneira, o que se observa em Corsaletti é a sua capacidade de resgatar elementos extraliterários, como dados psíquicos, emotivos e biográficos, retrabalhá-los formalmente, lançando-os em uma nova categoria: o biográfico se dilui no poético. "Acontecia às vezes", "meu avô morto", "Tomates", "Parceria", "Pela avenida", "Meninos soltando pipa”, "Sem acordo", "Memória dos dias comuns", são todos poemas que apontam o resvalo de uma categoria em outra, ficando patente a utilização de uma estratégia específica responsável por possibilitar tal poesia: a memória. $\mathrm{O}$ eu-lírico transita habilmente entre o quintal (em "Acontecia às vezes") e a rua da cidade grande (em o "Cãozinho") a partir da memória. Fatos e reminiscências são contados, colocando em evidência algo que a memória revela: importância do passado para tal eu-lírico. No entanto, esse passado se apresenta como constituinte de um eu no tempo presente, pois ele não canta e vangloria aqueles dias. $\mathrm{O}$ apego ao passado revela, ao contrário, uma necessidade de mover-se, de ir adiante. Através da memória, ele alcança seu passado, reexamina-o, para, finalmente, reforçar a ideia de busca de um outro espaço, que não aquele.

Embora todas essas informações até aqui elencadas - e cujos desdobramentos analíticos - possam representar motivo por si só para justificar a análise da obra de Corsaletti no cenário da poesia contemporânea, há uma especificidade em sua escrita que a situaria nas discussóes a respeito do presente e da crise que a literatura se propóe a responder. Sua poesia apresenta-se como essencialmente problemática porque mais do que ser voz de uma subjetividade que se pretende como lírica, ela plasma a estrutura do tempo presente em seus poemas. A ausência, a anulação e a indiferença são as marcas de um tempo que aponta incessantemente para o excesso, mas que na verdade constitui-se de vazios: o excesso de cuidado com a saúde, com a alimentação, com o bem-estar, com o presente, com a satisfação pessoal e com a realização dos desejos caminha exatamente em direção ao zelo extremado do indivíduo consigo mesmo e a sua agoridade, sendo o nada a noção que mais desse aspecto aproxima. O caminho do excesso é assim descrito: 
Levando-se em conta apenas o século XIX e XX, devemos evocar e citar, mesmo que fora de ordem, o desenraizamento sistemático das populaçôes rurais, depois urbanas, os langores românticos, o spleendandy, Oradour, os genocídios e etnocídios, Hiroshima devastada em dez quilômetros quadrados (...), os milhôes de bombas jogadas sobre o Vietnã e a guerra ecológica com produtos herbicidas, a escalda do estoque mundial de armas nucleares, Phnom Penh espoliada pelos Khmers vermelhos, as figuras do niilismo europeu, os personagens mortos-vivos de Beckett, a angústia e a desolação interior de Antonioni, Messidor de A. Tanner, o acidente de Harrisburg... com certeza a lista se alongaria desmesuradamente se quiséssemos inventariar todos os nomes do deserto. Alguma vez teremos organizado, edificado, acumulado tanto e, ao mesmo tempo, teremos sido alguma vez tão fascinados pelo nada, pelo impulso de suprimir tudo que existe, de chegar à exterminaçáo total? (LIPOVETSKY, 2005, p. 17)

A apatia new look (LIPOVETSKY, 2005, p.19) seria uma dessas manifestaçóes do "nada" em nossos tempos. Ela se configura como apatia - e não como niilismo - e é observada em relação a vários aspectos da vida: o jovem em relação à vida escolar, os homens em relação à política, por exemplo. A escola e a política, ou seja, espaços e instâncias que são instituídos coletivamente deixaram de representar a sociedade contemporânea constituindo hoje espaços desativados. Dessa maneira, o narcisismo coletivo seria um sintoma do avanço e da consolidação do individualismo que se situa nas origens da modernidade ${ }^{6}$. Ele aparece como uma condição de deserção do sujeito frente a questốes que o colocariam verdadeiramente situado no mundo. Essa tendência à desativação de diversas instâncias na contemporaneidade é o que parece ser incorporado à poesia de Corsaletti, uma vez que ela insinua a "desativação" da própria linguagem. Isto é, a apatia das metáforas aponta para a ausência

6 Seguindo essa perspectiva de autor, a indiferença moderna é diagnosticada no presente como potencializada, sendo a noção de ruptura entre a modernidade e uma "pós-modernidade" rechaçada. A sensação, portanto, é de continuidade e principalmente de agravamento das circunstâncias. 
do artesanato da linguagem, sendo a poesia sempre criticamente considerada in-suficiente e in-gênua. Constando no cenário do presente, a poesia de Corsaletti integraria, portanto, esse panorama da carência:

E se, para a crítica, a poesia tem parecido escassa, sempre em falta, sistematicamente acuada diante dos acontecimentos, é possível dizer que 'a poesia' é um nome adequado para designar a própria sensação crítica de falta e de acuamento. 'A poesia' torna-se o nome daquele lugar discursivo em que a linguagem crítica obsessivamente manifesta um questionamento sobre a situação contemporânea, por meio do qual, de certo modo, numa espécie de monólogo dramático, lamenta a falta de grandes questóes, de comprometimento, de negatividade compatível com a crise que fundamenta esse vazio. 'A poesia', no discurso crítico, é o topônimo da carência que perturba. (SISCAR, 2010, p. 176).

Ainda que fundada na condição da falta, essa poesia revela uma complexidade na constituição da subjetividade lírica, pois ela é repleta de oscilações. Isto é, a ausência do artesanato da linguagem em Corsaletti, resultante daquela desativação, explicita uma "poética de menos", fundada nas tensôes entre o excesso e o vazio, a apatia e o páthos, a violência e a delicadeza que constituem a tragicidade ${ }^{7}$ desse sujeito lírico contemporâneo. A leitura que este trabalho propóe, então, é que, por esta "Poética de menos", é possível compreender como a obra de Corsaletti estabelece uma leitura de seu tempo, uma vez que, calcada paradoxalmente na falta e nos excessos do presente, essa poesia se vale de recursos e procedimentos que avalizam o menos, a negação, a elipse e o esvaziamento, sempre tensionados com uma violência e com um ímpeto em direção ao descomedimento e ao excesso. Ainda portador da insígnia moderna - não menos tensa - da necessidade de escrever frente a toda condição de hos-

7 Considera-se o caráter trágico como aquela condição da qual o ser não consegue fugir, uma vez que se encontra amarrado a seu destino e às fatalidades que suas escolhas lhe impóem. Desse modo, o sujeito lírico em Corsaletti percebe-se situado em um tempo e atrelado a condiçóes das quais não pode desertar, quais sejam, a falta e o excesso que perpassam a contemporaneidade. 
tilidade no auge do capitalismo e de sua impossibilidade e de seu fechamento rumo ao silêncio, o texto de Corsaletti opera dialeticamente a violência através de uma linguagem simples e "pouca" de modo radical.

Considerando a proclamação da crítica a respeito de Corsaletti ser um aprendiz bem-sucedido das liçôes de Carlos Drummond de Andrade e de Manoel Bandeira ${ }^{8}$, questiona-se aqui se terá Corsaletti herdado destes ${ }^{9}$, no sentido de partilha da tradição literária conforme propóe T.S. Eliot, o pathos melancólico ${ }^{10}$, no sentido de que seria a apatia e sensação de esgotamento condições decorrentes desse estado melancólico? Isto é, seria ele ainda atravessado pela cosmovisão moderna do lírico que se depara com a destituição das tradições, em que "o topos melancólico é tomado como aparato metafórico de investigação das relaçôes estabelecidas entre a poesia e o mundo (...), no curso desse tempo que tomou a noção de ruptura e a busca do novo como seus valores fundamentais" (VASCONCELLOS, 2009, p.22)?

A partir das consideraçóes de Vasconcellos identifica-se uma ampla gama de condiçóes que remetem à melancolia, como

a angústia, em Kierkegaard, e também em Heidegger; o absurdo existencial, de Schopenhauer, a náusea, de Sartre, o ressentimen-

8 O artigo de Ronaldo Bressane, Impostor, publicado no "O Globo",faz as seguintes apreciaçóes críticas: "Com as liçóes de Oswald, Drummond e Bandeira na ponta do lápis, o poeta paulista Fabrício Corsaletti estreia (sic) pela Cia. das Letras em antologia que atualiza o modernismo - sem ser chato” e, também, “(...) a primeira antologia poética do paulistano Fabrício Corsaletti, Estudos Para o Seu Corpo (...) começa já meio com soluço - o autor tinha 23 anos quando o publicou pela primeira vez (tem agora 29) -, mas decididamente com timbre seguro, ecoando duas marcadas referências: Drummond e Bandeira.", partindo da argumentação de que Corsaletti possui, assim como os dois poetas a "capacidade de catar no coloquial o instante poético", bem como "ater-se ao essencial beirando o simples, elegendo como alvos temas tão velhos quanto a infância, a província ou o erotismo, são riscos friamente calculados pelo poeta, que os dribla com humor." O Globo, 30-6-7. "Meu amor me ensinou a ser simples". Postedon 1, 14, julho, 2007.

9 Em entrevista a Ronaldo Bressane, respondendo à pergunta "Quais são seus poetas favoritos?", Corsaletti afirma declaradamente: "Drummond, Bandeira, Rimbaud, Baudelaire, Neruda.". Essas escolhas afetivas podem representar, certamente, um certo diálogo com a poesia dos dois primeiros.

10 Em sua tese "Melancolia e crítica em Carlos Drummond de Andrade", Viviane Vasconcellos apresenta a melancolia como um operador textual para a confecção da poesia em Drummond e YudithRosenbaum em Manuel Bandeira: uma poesia da ausência apresenta também a melancolia como qualificadora da poética do poeta pernambucano (2002, p. 29). 
to, em Nietzsche; o sofrimento do protagonista de Werther, de Goethe; a melancolia, de Dürer; mesmo o tédio, de Baudelaire, a nostalgia, de Proust, além do horror, em Kafka, o luto pelo não-vivido, em Thecov, ou, entre nós, em Manuel Bandeira, e Emílio Moura; a depressão, para a psiquiatria moderna; também, o luto e a melancolia, em Freud. (VASCONCELLOS, 2009, p.23-24)

Não seria, portanto, a apatia do sujeito lírico em Corsaletti uma outra constituição/nomenclatura da melancolia moderna, rearranjada conforme a condição da contemporaneidade histórica?

Sendo a melancolia amplamente compreendida como uma "afecção (do grego: melas: negro, chole: bile) (...) caracterizada por um desequilíbrio humoral, que acarreta uma oscilação entre dois estados psíquicos opostos: o humor depressivo e o humor exaltado (...)", (VASCONCELLOS, 2009, p. 23) certamente a poesia de Corsaletti assume uma dicção humorada que oscila entre o tom depressivo e o chiste, a exemplo dos poemas "Parceria", "Cãozinho", "orelhas", "nariz". Bressane também sinaliza a escolha do poeta em tratar de temas "já velhos", mas que são riscos friamente calculados pelo poeta, que os dribla com humor. Essa oscilação dos estados psíquicos - materializada em grafia do sujeito lírico - seria, portanto, um indicativo de que a melancolia figura em sua poesia.

No entanto, há alguns traços que devem ser levados em consideração a fim de se pensar o estado melancólico para avaliá-lo como operador textual da poesia de Corsaletti e que diz respeito às implicaçóes patológicas mesmas apresentadas por Freud:

A melancolia se caracteriza psiquicamente por um desânimo profundamente doloroso, uma suspensão do interesse pelo mundo externo, perda da capacidade de amar, inibição de toda atividade e um rebaixamento do sentimento de autoestima, que se expressa em autorrecriminaçôes e autoinsultos, chegando até à expectativa delirante de punição. (FREUD, 1992, p.131)

O presente trabalho, no entanto, diagnostica a sensação da "apatia" em sua poesia de maneira mais retesada do que o tom melancólico em si. Ora, apesar de muita da constituição melancólica se aproximar da perspectiva pela 
qual o eu lírico em Corsaletti vê o mundo, esta condição parece se orientar por uma forte sensação de aniquilamento do ser, isto é, negatividade que se estende de maneira desoladora enquanto os poemas analisados aqui explicitam esse aniquilamento, mas de forma "apática", conforme a própria etimologia do termo grego mostra: páthos é entendido como "paixão, fato de sofrer; e o prefixo privativo ' $a$-: sem paixão'”, sendo que os termos podem ser utilizados em dois sentidos: "metafísico: impassível = que não pode receber nenhuma afeição." e "moral: insensível = livre das paixôes. Esse estado é então a apátheia, impassibilidade, apatia.” (GOBRY, 2007, p. 22).

A análise do poema possibilitará a verificação de como a "apatia" e a "falta" se estabelecem como operadores textuais na escrita de Corsaletti, caracterizando a tensão entre a forma artística e o processo histórico. Ainda se valendo de categorias da modernidade, "A aranha", expóe a fratura que passa a constituir a subjetividade lírica a partir da enunciação de Rimbaud "Je est unautre" e que ainda configura o eu na produção contemporânea:

Não importa a idade, a aranha

em algum momento

se cansa e não quer mais

atear suas lentas cordas no espaço

infinito. $\mathrm{O}$ mundo lhe parece

veloz e estranho, e raramente ela deseja

ser veloz. Está liquidada, e segue em linha

reta, sem olhar para os lados,

porque os movimentos circulares a entontecem;

além de duvidar da suposta liberdade

que a loucura de caminhar em labirintos elásticos

pudesse lhe dar: crê que o louco sabe que é louco.

Enfim, ela quer um ritmo justo.

Eufórica, esse ritmo (que ela apenas intui)

se transforma, e de olhos fechados, escura e fosca,

ela sonha ser - mas isso seria a alegria! -

uma enguia num mar branco,

um límpido escaravelho.

(CORSALETTI, 2007, p. 102) 
Isto é, apesar de o sujeito lírico se valer da terceira pessoa - tendo como índice o verbo est, forma verbal da terceira pessoa do singular no francês, Il/ Elle - para se referir à "aranha", a intimidade com as ânsias desse ser passa automaticamente a ser compreendida como a usurpação da imagem do inseto e de seus qualificativos como a inferida teia ("não quer mais / atear suas lentas cordas no espaço / infinito”) que, personificados através da caracterização subjetiva (" não quer", "lhe parece”, "deseja”, "duvidar"), conformam a imagem do eu lírico $(\mathrm{Je})$. Assim, a identidade entre sujeito e a aranha se constrói na esteira da constatação de que o eu é cindido e perpassado por inúmeras vozes e possibilidades: assim como ele pode ser "aranha", a projeção e o sonho também podem configurá-lo como "enguia” e "escaravelho".

No entanto, o mais significativo no fato de o eu lírico estar travestido em animais os mais variados é a constante permanência do cansaço e da negatividade como traço de todos os três. Em oposição à objetividade de um mundo que "lhe parece / veloz e estranho" o eutransmudado em aranha "se cansa", "não quer mais / atear suas lentas cordas no espaço / infinito", pois está "liquidada"; o caminho que deseja é oposto às redes que configuram sua teia - espaço entrelaçado de caminhos aparentemente livres, mas já pré-determinados e "da suposta liberdade / que a loucura de caminhar em labirintos elásticos / pudesse lhe dar" -, uma vez que o "ritmo ( que ela apenas intui)" é o do deslizar da "enguia num mar branco". Isto é, inserido na dinâmica de seu presente, o eu lírico explicita seu mal-estar diante de seu tempo através de uma perspectiva negativista, uma vez que a recusa desse estado é a tônica do poema, apresentando como sintoma desse mal-estar o "cansaço".

A imagética do poema reforça a oscilação entre o que está posto para esse sujeito e o que se deseja, sendo particularmente plástica essa oscilação. O "espaço infinito", a "linha reta", os "movimentos circulares", os "labirintos elásticos", exprimem a tirania do movimento supostamente livre ("suposta liberdade") que ao eu é permitido seguir em oposição ao "ritmo justo" e intuído possibilitado pelo movimento deslizante e fluido. Assim, o eu-aranha se caracteriza pelo movimento limitado e labiríntico, enquanto a enguia e o escaravelho simbolizam a possibilidade do movimento deslizante. A oscilação entre a constituição da subjetividade, portanto, é a primeira das questôes que esse poema propóe. Em consonância com a constituição fraturada referida acima, o eu desse poema também é um outro, mutante. 
Além disso, a oscilação é também de outra ordem, pois se erige entre os caminhos do eu: o presente lhe permite os "labirintos elásticos" sendo que a alegria (" - mas isso seria a alegria! - ") seria o puro deslizar "de olhos fechados, escura e fosca (...) num mar branco". Formalmente a opção do sujeito lírico poderia ser compreendida pela oscilação da "aranha" inicial do texto (a do título) em direção à sua transmudação nas imagens da enguia ou no límpido escaravelho. A opção, portanto, seria a oscilação no sentido de um ritmo da intuiçãoo e possível de alergia.

Materializando a oscilação dos movimentos possíveis, os versos espraiados revelam o cuidado com a escritura. Ora, desde o primeiro até o décimo segundo, os versos sáo majoritariamente fraturados, sendo o enjambement significante do movimento empreendido pela aranha em sua teia "em labirintos elásticos". Afinal, ela também inserida em um ambiente em que a fragmentaçấo e o corte são as condiçôes resultantes de um mundo "veloz e estranho". Por esse motivo, o eu tenta impor um ritmo possível, a saber, o da "linha reta", freando as quebras dos versos: do sexto para o sétimo verso o enjambement entre o verbo e seu complemento ("deseja / ser veloz") explicita a tentativa de diminuir a velocidade desse mundo ao diminuir a velocidade de leitura do verso. A partir do décimo terceiro verso, quando se enuncia o desejo por um "ritmo justo", as frases poéticas assumem uma forma deslizante, sendo a quebra sintática rechaçada em favor da fluidez da manutenção da oração.

Diante da oscilação dos movimentos, o que resta ao sujeito lírico - dividido entre a aceitaçấo do presente "veloz e estranho" e a impossibilidade do deslizar porque sabe que é sonho - é a negatividade, aqui manifestada não como negação via destruição, mas justamente como negaçáo via apatia. Os versos sete e oito conformam essa condiçâo do cansaço e da ausência: "Está liquidada, e segue em linha / reta, sem olhar para os lados". "Liquidada" e "em linha reta", as expressóes utilizadas são da ordem do esgotamento e da fadiga, coadunando assim com o vocabulário em geral, como "se cansa", "não quer mais", "raramente ela deseja", "movimentos circulares a entontecem", "duvidar da suposta liberdade".

Juntamente a esse vocabulário, percebem-se alguns índices de indeterminação, como "não importa", "em algum momento", "não quer mais", "sem olhar para os lados", que marcam uma deliberada indiferença do sujeito lírico 
frente ao tempo em que vive. Respondendo ao questionamento "Por que raios fazer poesia hoje?” (BRESSANE. Meu amor me ensinou a ser simples, 2007), Corsaletti expóe o fato de situar-se filosófica, política e esteticamente em seu tempo, afirmando: "Não dá pra escolher em que época nascer. Nasci nessa época. Então é nela que vou escrever.". Desse posicionamento, portanto, infere-se que o sujeito lírico responde também deliberadamente a uma época de apatia fazendo explodir no texto as marcas da apatia em si.

Assim, a tensão entre as imagens desse poema representa o embate entre a instância do páthos e uma orientação literária que se realiza pela contenção, na direção do menos. Considerando o discurso poético basicamente um exercício da palavra, o texto de Corsaletti, ao se erigir pelo cansaço, pela liquidez e pela opção da reta - instâncias negativas - em detrimento do elaborado e da construção, dá mostras de isentar sua poesia daquele papel. Nesse sentido, o exercício poético revela-se desmerecido, embora - e é aí que reside o paradoxo - ele aconteça, mesmo que por sinais de "menos".

Em consonância a esse impasse da escrita poética, a metáfora da aranha, que se identifica ao sujeito lírico, reforça a condição de esvaziamento do texto. Ora, sendo a aranha responsável pela tessitura de suas teias, a ideia de tecer funda metalinguisticamente a confecção do texto. Entretanto, como se observa no poema, ela "se cansa/ e não quer mais / atear suas lentas cordas no espaço / infinito". Ao recusar a manipulação desse tecido/texto, o poema se realiza pelos solavancos de uma escrita que se faz na tensão entre o imperativo do escrever e a paralisia do discurso.

Finalmente resta avaliar a identificação entre sujeito lírico e a aranha, partindo do questionamento o que é ser aranha no tempo presente, isto é, em que sentido a aranha estava qualificando a vida do eu. Conforme descriçóes do comportamento dos aracnídeos, de modo geral a maioria das espécies corre muito rapidamente, com movimentos bruscos, o que certamente pode ser compreendido como condiçáo de existência do indivíduo contemporâneo, forçado a se envolver nas redes e teias geométricas que os costumes, as imposiçóes, as escolhas e os desdobramentos do cotidiano vão definindo e redimensionando. A recusa do eu lírico em aderir a essa dinâmica, bem como a impossibilidade de seguir o utópico caminho deslizante da "enguia num mar branco", delineiam mais uma vez a tensão entre o excesso e o esvaziamento que sua poesia acena, 
materializada pela escolha da reta. É o caminho da dispersão e representativo de nenhum traçado a priori, o contrário das redes e teias, portanto, que o sujeito lírico deseja. A impossibilidade de seguir o caminho deslizante daquela enguia impóe a ele a escolha pela reta, pelo não acidental, pelo equilíbrio e pela apatia.

A constatação de que o caminho da reta no momento presente - que implica essencialmente a condição do menos - é a única possibilidade que acena para o eu lírico se origina da sensaçáo contemporânea decorrente da obsessão pela expressão (LIPOVETSKY, 2005, p.XXIII). Ora, de acordo com o pensador francês, ocorre neste tempo de aceleração dos costumes e a intensificação do "processo de personalização" um deslumbre em relação à possibilidade de se realizar como "indivíduo total", isto é, indivíduo que não somente percebe o valor de suas escolhas individuais, mas que as cultua e as reconhece como direitos inalienáveis, afinal é a partir delas que constitui e direciona sua existência. Dentre o rol dessas escolhas que afirmam a legitimação da personalidade, a necessidade de expressar-se e definir-se como existência exclusiva é notável e gera uma

democratização sem precedentes da palavra: todo mundo é incitado a ligar para a central telefônica, quer contar algo a partir de sua experiência íntima, ou pode tornar-se locutor e ser ouvido. Isso vale tanto nesse caso como no dos grafites nas paredes de escolas ou no dos inúmeros grupos artísticos: quanto mais a gente se expressa, menos há o que dizer; quanto mais a subjetividade é solicitada, mais o efeito é anônimo e vazio. Esse paradoxo é reforçado também pelo fato de que ninguém, no fundo, está interessado nessa profusão de expressóes, com uma exceção que deve ser levada em conta: o próprio emitente ou criador. (...) Daí essa pletora de espetáculos, de exposiçóes, de entrevistas, de proposiçóes totalmente insignificantes para qualquer pessoa e que náo levam em conta nem mesmo a ambiência; outra coisa está em jogo: a possibilidade e o desejo de se expressar qualquer que seja a natureza da 'mensagem', o direito e o prazer narcisista de se manifestar a respeito de nada, por si mesmo, mas retransmitido e amplificado por um meio 
de comunicação. Comunicar por comunicar, expressar-se sem qualquer finalidade a não ser expressar-se e ser ouvido por um micropúblico, o narcisismo revela, tanto aqui quanto em outros aspectos, a sua conivência com a ausência de substância pósmoderna, com a lógica do vazio.” (LIPOVETSKY, 2005, p. XXIV)

É denunciando este tempo de obsedação pela expressão de si a todo custo - e que constitui as redes nas quais ela caminha - e também percebendo a ilusão de tornar-se uma legítima expressão - símbolo da enguia ou do escaravelho -, que o eu simbolizado pela aranha opta pela tensa expressão que a reta insinua, isto é, a materialização da tentativa de calar o excesso em direção a uma escrita de menos.

Assim, participando também dessa tensão, considerando-se o fato de que ninguém, no fundo, está interessado no bombardeamento das expressóes alheias, este poema opera em dois sentidos: primeiramente, na denúncia de que o presente é tempo de ausência (mesmo que aparentemente figure o excesso) a partir da constatação de que envolver-se nas suas teias e aceitar a velocidade demonstram a conivência com o mesmo (e, portanto, conivência com aquelas condiçóes); em segundo lugar, contraditoriamente aponta que o eu, mesmo seguindo pelo caminho da reta, também se insere na ordem do comunicar por comunicar. Desse modo o poema se constrói pelo embate entre a constatação da falta e a enunciação da falta.

Essa marca paradoxal da poesia de Corsaletti não deixa de retomar o caráter atravessado da lírica, que, tencionando sujeito e mundo, explicita a fratura de que fala Adorno. Tentando resgatar a unidade entre a natureza e o eu, o sujeito desde a modernidade tenta esboçar uma representação de si que ecoa a harmonia. Sabe-se, entretanto, que essa tarefa já é de antemão tensa e não solucionada, e isso ocorre especialmente na poesia que aqui se analisa. Já não tão próxima do contexto em que as proposiçóes de Adorno se colam, a obra de Corsaletti se constrói sob a égide de algumas condiçóes que se agravaram com a consolidação do individualismo e com toda a trama paradoxal que lhe é característica. $\mathrm{Na}$ esteira de considerar as tensôes como fundadoras do tempo presente, o paradoxo emerge como insígnia maior nas argumentaçôes de Gilles Lipovetsky. Considerando que o modelo de sociedade disciplinar 
foi substituído por um modelo "pós-disciplinar" (LIPOVETSKY, 2005), o processo de personalização traçou caminhos que apontaram para o ápice da autonomia, gerando ao mesmo tempo instâncias de responsabilidade e do total desregramento em relação aos costumes. O paradoxo se tornou, afinal, a condição máxima desses tempos. Assim, a "poética de menos", que se observa na lírica de Corsaletti, orienta-se por levar em consideração o caráter essencialmente tenso das relaçóes e das condiçóes de existência da contemporaneidade.

Paradoxalmente a tensão de tal caminho é materializada pela reta, ou seja, um caminho sem desvios nem ziguezagues, ritmado, despojado e vidrado: caminho em consonância com as condiçōes de exaustão, desencanto, monotonia, esgotamento e apatia apresentadas por Lipovetsky. Pode-se afirmar que a poesia de Corsaletti plasma à sua estrutura tais instâncias através dos recursos poéticos que balizam o "menos". Assim, a utilização de um vocabulário de "menos", a dicção elíptica, a construção marcada pelo enjambement e pelos cortes sintáticos no interior do verso mesmo, a contenção dos versos em poucos vocábulos e a reincidência de um léxico que sinaliza a ausência, a negatividade e o afastamento do sublime poético de Hegel explicitam um aparente "desleixo formal" que, na verdade, encena a tensáo que se opera nesse tempo. Isto é, a arquitetura do texto de Corsaletti revela-se simples e despojada ao mesmo tempo em que mostra a densidade e a violência de um texto que esconde/sugere a sensaçáo do sujeito contemporâneo. A economia de procedimentos acaba por materializar a vivência de um sujeito lírico situado historicamente e marcado pela densidade de presente esvaziado de experiências, isto é, um texto que traduz a insígnia da falta manifestada através de contradiçốes fundadoras alicerçadas em um tempo histórico não menos contraditório que este. Em outras palavras, Corsaletti violenta através dos recursos de "menos" o discurso lírico, esvaziando-o na radicalidade das tensóes. Sua poesia, enfim, expressa uma simplicidade aliada a complicadores, como a fronteira limítrofe entre sujeito empírico e lírico, avalizada pela linguagem coloquial e simples que se impóe como contraditoriamente tensa, revelando uma dificuldade da voz lírica, que por sua vez tem a sua frente o presente sempre por fazer através da projeçáo de sua subjetividade e da sua linguagem no mundo.

Percebe-se, desse modo, o projeto de a subjetividade lírica em Corsaletti 
ler e dar forma, pela escritura, ao seu presente, plasmando a condição de "falta” que emerge da contemporaneidade. Sendo assim, a argumentação retorna aos três pontos iniciais a fim de se compreender o movimento empreendido pela lírica contemporânea: a constatação da falta do presente, a constatação da falta que constitui o discurso literário como possibilidade de construção interpretativa e figural do poeta em sua poesia e, finalmente, a assunção do analista em relação a sua leitura do objeto literário, que se opera também como "desvio da forma”. Estes operam como índices de que a literatura, por estar essencialmente ligada ao presente, constitui-se atravessada pela crise. Dessa maneira, observando o papel que cabe ao discurso crítico, uma das exigências a que este texto tentou se regular é relativa à atenção ao que perpassa e funde o tempo presente.

Compreender o presente como questão, neste trabalho, significou perceber que a análise da obra de um autor que seja coetâneo ao crítico não implica seja na extrema afinidade seja na absoluta condenação de uma poesia que prescinde da passagem do tempo para decantar suas potencialidades ou seus vícios. $\mathrm{Na}$ verdade, considera-se aqui a impossibilidade de ignorar a produção poética contemporânea, justamente porque este fato coincidiria com a possibilidade de se ignorar o próprio tempo. Desse modo, cônscios de que o olhar do analista é de quem recorta, seleciona, edita, enfim, toma o discurso literário como figura, este trabalho se orientou no sentido de tomar a poesia contemporânea a fim de perceber a condição da lírica brasileira, perpassada por todos os embates, isto é, pela crise que continua a constituindo. Identificadas as limitaçóes desse discurso que se enuncia para assinalar seu fracasso, a poesia de Fabrício Corsaletti se esforça por dramatizar a sua falta.

\section{Referências:}

AGAMBEN, Giorgio. O que é o contemporâneo? e outros ensaios. Chapecó, SC: Argos, 2009.

BRESSANE, Ronaldo. "Meu amor me ensinou a ser simples". O Globo, 30 Jun.2007. Publicado em 14, jul. 2007.

CANDIDO, Antonio. Formação da Literatura Brasileira: momentos decisivos. Rio de Janeiro: Ouro sobre Azul, 2006. 
CARPINEJAR, Fabrício. Versos de incômoda ressaca. Resenha publicada a propósito da participação de Fabrício Corsaletti na FLIP-2007. Disponível em http://recorte.org/flip2007/fabricio-corsaletti/. Acesso em 23 Abr. 2011.

CORSALETTI, Fabrício. Estudos para seu corpo. São Paulo: Companhia das Letras, 2007.

DOLHNIKOFF, Luis. Fabrício Corsaletti ou 'Honoris causa é horsconcours'. Disponível em: http://www.sibila.com.br/index.php/estado-critico/1008-fabricio-corsaletti-ou-honoris-causa-e-hors-concours. Acesso em: 31 Mai. 2012.

FREUD, Sigmund. Luto e melancolia (1917). Tradução de Marilene Carone. Novos Estudos CEBRAP, No 32, março 1992, pp. 128-142.

FRIEDRICH, Hugo. Estrutura da lírica moderna: da metade do século XIX a meados do século XX. São Paulo: Duas Cidades, 1978.

GOBRY, Ivan. Vocabulário grego da filosofia. São Paulo: WMF Martins Fontes, 2007.

LIPOVETSKY, Gilles. A era do vazio: ensaios sobre o individualismo contemporâneo. Barueri, SP: Manole, 2005.

MACHADO, Carlos. Apresentação de Fabrício Corsaletti. São Paulo, 25 de julho de 2007. Disponível em: http://www.algumapoesia.com.br/poesia2/poesianet219.htm.Acesso em: 23 Abr. 2011.

ROSENBAUM,Yudith. Manuel Bandeira: uma poesia da ausência. São Paulo: Editora da Universidade de São Paulo, 2002.

SISCAR, Marcos. Poesia e Crise: ensaios sobre a "crise da poesia" como topos da modernidade. Campinas, SP: Editora da Unicamp, 2010.

VASCONCELLOS, Viviane. Melancolia e critica em Carlos Drummond de Andrade. 2009. 200f. Tese (Doutorado em Letras) - Faculdade de Letras, Universidade Federal de Minas Gerais, Minas Gerais, 2009. 


\title{
ABSENCE AND CRISIS IN CONTEMPORARY BRAZILIAN POETRY: THE 'LACKING' WRITING IN FABRÍCIO CORSALETTI.
}

\begin{abstract}
The aim of this paper is to present a brief analysis on the situation of the contemporary Brazilian poetry, especially through the work of FabrícioCorsaletti. By using the points brought by Marcos Siscar and the analysis made by Gilles Lipovetski this text approaches the consideration that Corsaletti's poetry performs the crisis in his 'lacking' writing, i.e. Corsaletti's lyric embodies the present condition in its shape assuming that the absence is the pattern grounded in his time.

KEYWORDS: Poetry. 'Lacking' writing. Fabrício Corsaletti.
\end{abstract}

Recebido em: 18/09/2014 Aprovado em: 15/01/2015 